\title{
Ionic Liquids: Simple or Complex Electrolytes?
}

\author{
Marija Bešter-Rogač $\check{c}^{\star}$ \\ University of Ljubljana, Faculty of Chemistry and Chemical technology, Večna pot 113, SI-1000 Ljubljana, Slovenia \\ ${ }^{*}$ Corresponding author: E-mail: marija.bester@fkkt.uni-lj.si \\ Received: 01-30-2020 \\ Paper presented as a key-note lecture at the $25^{\text {th }}$ Annual Meeting of the Slovenian \\ Chemical Society, Maribor, 25.-27. 9. 2019 and \\ dedicated to the memory of Professor Josef Barthel, who passed away in February 2019.
}

\begin{abstract}
Ionic liquids belong to the most investigated systems in the recent years and this field is still significantly growing with an increased focus on developing ionic liquids for specific applications, along with fundamental research. In the present featured paper the similarity and differences between common, "classical" electrolytes and common surfactants and ionic liquids along with the surface-active ionic liquids are discussed in order to stress their significance and point out on their weak points. A short survey of the literature data reveals namely that ionic liquids in solutions behave like "classical" electrolytes and can be described by existing models in the range of their validity. There is still a lack of models describing well the concentrated electrolyte solutions and here ionic liquids, less limited by solubility as common electrolytes, can serve as model systems. The micellization of surface-active ionic liquids in aqueous solutions can be described in the same way as for common surfactants, but surface-active ionic liquids offer more possibilities to study specific ion and isomer effects. They are also quite promising systems to study the aggregation processes in non-aqueous solutions.
\end{abstract}

Keywords: Ionic liquids; surface active ionic liquids; aqueous solutions; non-aqueous solutions

\section{Introduction}

Ionic liquids (ILs) are molecules composed of anions and cations in which at least one component is an organic molecular structure that hinders efficient close packing. Thus, their melting point temperatures are below $100{ }^{\circ} \mathrm{C}$ which differentiate them from typical inorganic salts.

ILs can have useful physical properties, such as low volatility, and are often used as solvents and electrolytes. As suitable systems for a wide range of applications they attracted the attention of many researchers.1 It turned out ${ }^{2}$ that ILs are more complex than molecular solvents and thus their bulk and interfacial structures are markedly different. They show rich structural diversity both in the nature of ions that can be employed as well as in the organization of these ions in the liquid phase. A sample of representative popular anions and cations chemical structures usually used in ILs is presented in Figure $1 .{ }^{2}$

By increasing the cationic alkyl side-chain length even the transition from the known spatially heterogeneous structure to a liquid crystal-like phase was observed. ${ }^{3}$

However, the growing number of reviews dealing with the physicochemical properties of ILs in their pure state has been extended to investigations of their mixtures with molecular cosolvents. It has been shown that ILs in solutions can serve as excellent model (electrolyte) systems, because they exist in diverse structures and the hydrophobic part of the cation can be varied almost optionally. Investigations of ion association of ILs in diverse organic solvents reveal namely that their ion pairing is entropy-driven and thus associated with cation desolvation, in line with the only moderate strength of cation-solvent interactions. ${ }^{4,5}$ The association of imidazolium based ILs as model 1,1-electrolytes in water solutions is weak but evidently dependent on the molecular structure (alkyl chain length), which also strongly affects the mobility of imidazolium cations. ${ }^{6}$ According to experimental and computational results, hydrophobic hydration of the side chain on the imidazolium ring is most responsible for structure making/breaking properties of investigated imidazolium salts. ${ }^{7}$ Ionic liquids with long alkyl chains behave similar to conventional surfactants forming aggregates in water, ${ }^{8}$ but due to possible variations in the chain length and counter-ions they are extremely appropriate for studying self-assembly processes in solutions.

Thus, ILs exhibit properties from simple salts to liquid crystal-like structures and there are still many unex- 


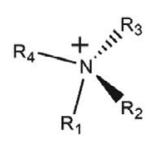<smiles>[R8][N+]1([13CH3])CCCC1</smiles><smiles></smiles><smiles>[R6]n1cc[n+]([Al]n2cc[n+]([R9])c2)c1</smiles>

CATIONS<smiles>[R7][P+]([R])([R5])[3H]</smiles><smiles></smiles><smiles>CCC1C[N+](C)(C)CC1CC</smiles><smiles>COCCOCCOCCOCCOC</smiles><smiles>[Y]C=O</smiles><smiles>O=[N+]([O-])[O-]</smiles><smiles>O=S(=O)([O-])O</smiles><smiles>O=C(O)CC=CC(F)(F)F</smiles><smiles>O=S(=O)(NS(=O)(=O)C(F)(F)F)C(F)(F)F</smiles><smiles>[3H][P-](F)(F)F</smiles><smiles>N=CSS</smiles><smiles></smiles><smiles>N#CNC#N</smiles><smiles>CC(C)CC(C(C)C)P(=O)([O-])[O-]</smiles><smiles>Cl[Te](Cl)(Cl)Cl</smiles>

Figure 1. Some chemical structures of representative cations and anions used in ionic liquids. From left to right, the cations (top row) include: ammonium, pyrrolidinium, 1-methyl-3-alkylimidazolium, 1,3-bis[3-methylimidazolium-1-yl]alkane; (second row) phosphonium, pyridinium, poly(diallyldimethylammonium), metal $\left(\mathrm{M}^{+}\right)$tetraglyme. The anions include (third row) halides, formate, nitrate, hydrogen sulfate, heptafluorobutyrate, bis(perfluoromethylsulfonyl)imide, tetrafluoroborate, (bottom row) thiocyanate, hexafluorophosphate, tris(pentafluoroethyl)trifluorophosphate, dicyanamide, poly(phosphonic acid), and tetrachloroferrate. Reprinted with permission from ref. ${ }^{2}$ https://pubs.acs.org/doi/10.1021/cr500411q. Further permissions related to the material excerpted should be directed to the ACS.

plored opportunities for manipulating their structure to control their functions and applications.

\section{Ionic Liquids in Their Pure State}

The large number of cation-anion combinations and the tunability of the cation and/or the anion structure offer possibility to synthesize ILs with targeted properties. In Figure 2 a schematic representation of the different types of possible interactions in an imidazolium-based ionic liquid is presented. ${ }^{9}$ In addition, the hydrophobicity of cation can be varied by the length of side alkyl chains.

Consequently, ILs in their pure state exist in very different structures. Figure 3 shows an example for the struc- tures in the bulk phase of imidazolium hexafluoro phosphate $\left(\left[\mathrm{C}_{\mathrm{n}} \mathrm{mim}\right] \mathrm{PF}_{6}\right)$, where the increase in the length of side chain from 2 to 12 carbon atoms leads from globular to sponge-like structure.

On the whole - dependent on the composition and building elements of an ionic liquid there are diverse possibilities for structuring - from ion pairs, hydrogen bond networking to ion clusters and - as seen already before - to self-assembled structures (Figure 4).

Thus, ILs even in their pure state form rather complicated and complex structures, whereas for example in sodium chloride, as the simplest electrolyte, the single unit has completely known and unique properties. Sodium and chloride ions have ascribed defined positions and so the structure of the $\mathrm{NaCl}$ crystal has no diversity,

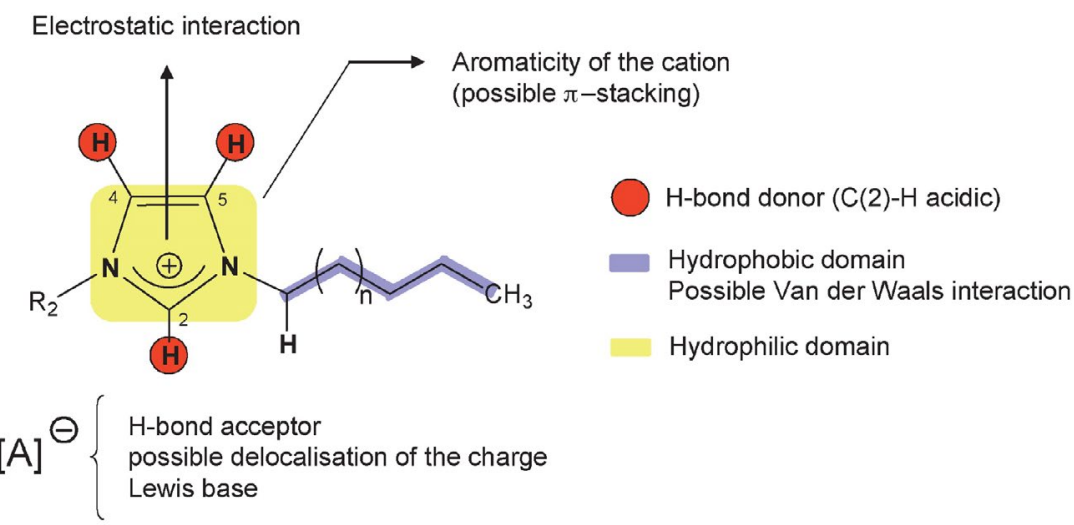

Figure 2. Schematic representation of the different types of interactions present in imidazolium based ILs. Reprinted from ref. ${ }^{9}$ with permission from Elsevier. 


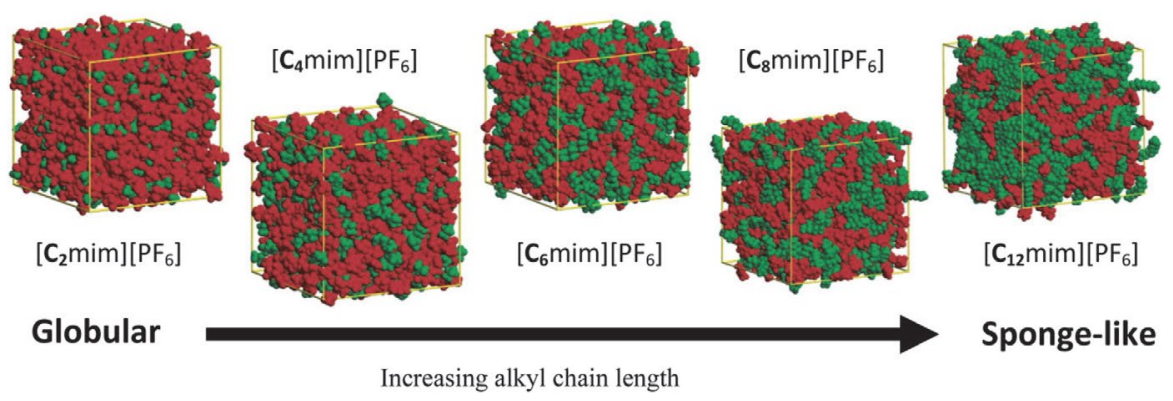

Figure 3. Snapshots of the bulk structure of $\left[\mathrm{C}_{\mathrm{n}} \mathrm{mim}\right] \mathrm{PF}_{6}$ ILs for $\mathrm{n}=2-12$. Each box shows 700 IL ion pairs at equilibrium with polar domains (red, anion + cation imidazolium ring) and nonpolar domains (green, cation alkyl chain) observed. Note that the box dimensions are not of the same length due to differences in ion size and box density. Reprinted with permission from ref. ${ }^{2}$ https://pubs.acs.org/doi/10.1021/cr500411q. Further permissions related to the material excerpted should be directed to the ACS.

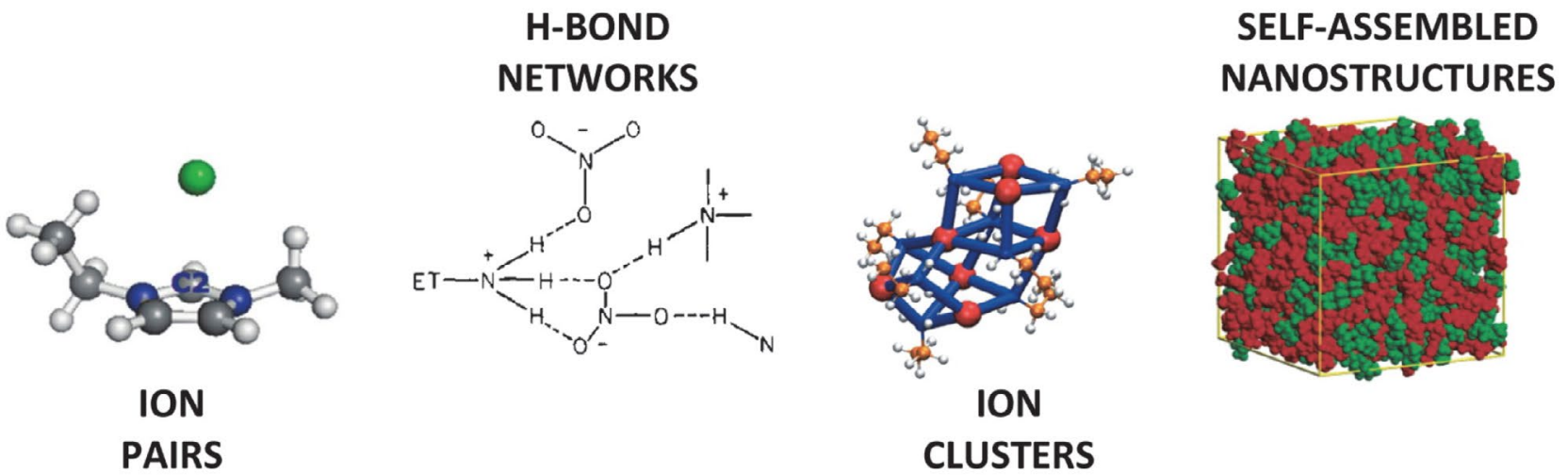

Figure 4. Different models for the bulk structure of ILs. See text for details. Reprinted with permission from ref. ${ }^{2}$ https://pubs.acs.org/doi/10.1021/ cr500411q. Further permissions related to the material excerpted should be directed to the ACS.

should be easily understood and thus it is simple in comparison to different structures of ionic liquids. Therefore, ionic liquids can without doubt be judged as complex electrolytes in their pure state. The reason for this complexity is - as already mentioned - mainly in the structure of cations.

\section{Ionic Liquids in Solutions}

Whereas understanding the properties of pure ILs is of fundamental interest, the practical applications generally require the admixture of other compounds, acting either as a reactant or product or as a cosolvent required for process optimization. ${ }^{10}$ Some earlier investigations ${ }^{11-14}$ reveal that addition of an IL in an organic solvent enhances the electrochemical and thermal stability of IL/organic solvent binary mixtures which often reflects in higher electrical conductivity and better device performances at low temperature than comparable mixtures of salts with high melting point temperatures. ${ }^{15}$

Recently, it has been demonstrated that ILs can serve as an excellent model system for investigating the influence of the ion structure on the mobility and ion pairing even in aqueous solutions, where the interionic interac- tions are weak. ${ }^{6,16,17}$ It turned out that due to possible variations in the structure of chain length and counter-ions the surface active ionic liquids (SAILs) have a great potential for investigation of micellization process in aqueous solutions. ${ }^{8,18,19}$ Even more, SAILs were used in investigations of aggregation behavior in non-aqueous solvents where solvophobic effect and the hydrogen-bonding interactions were found as the main factors controlling the aggregates formation. ${ }^{20,21}$

\section{1. Ionic Liquids in Aqueous Solutions}

Ion Mobility. Recently, the mobility and the mechanism of ion pairing in aqueous solutions were investigated systematically on nine imidazolium based ILs from 1-methylimidazolium chloride, $[\mathrm{mim}] \mathrm{Cl}$, to 1-dodecyl-3-methylimidazolium chloride, $\left[\mathrm{C}_{12} \mathrm{mim}\right] \mathrm{Cl}$, with two isomers 1,2-dimethylimidazolium chloride, [1,2-mim $] \mathrm{Cl}$, and 1,3-dimethylimidazolium chloride, $[1,3-\mathrm{mim}] \mathrm{Cl}$ in the line. ${ }^{6}$ The values of their molar electric conductivity - as still one of the most suitable quantity for investigation of electrolyte solutions - for diluted solutions of the studied ILs at $298.15 \mathrm{~K}$ are presented on Figure 5 together with the data for $\mathrm{NaCl}$ aqueous solution for comparison. 


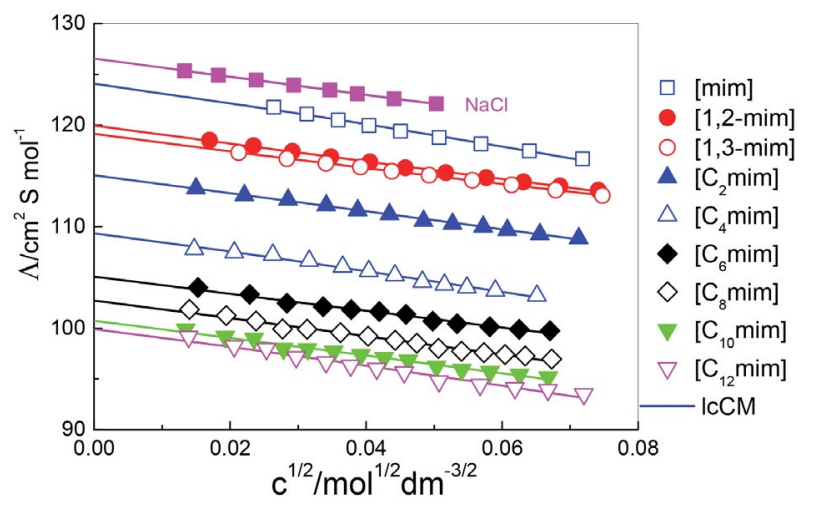

Figure 5. Molar conductivity of investigated imidazole based ILs chlorides ${ }^{6}$ and $\mathrm{NaCl}^{22}$ at $298.15 \mathrm{~K}$ in water; symbols denote experiment and lines $\mathrm{lcCM}$ calculations.

As one can see here, the values for $\mathrm{NaCl}$ are only slightly higher than those for $[\mathrm{mim}] \mathrm{Cl}$. So it can be assumed that studied ILs in diluted water solution behave like simple 1,1-electrolytes - molar conductivity is linear dependent on the square root of concentration.

The experimental molar conductivity of diluted IL solutions $(c \approx \leq 0.005 \mathrm{M})$ were analyzed in the framework of Barthel's low-concentration chemical model (lcCM) which describes successfully thermodynamic and transport properties of diluted solutions, yielding the molar conductivity of the solute at infinite dilution, $\Lambda^{\infty}$, and the standard-state (infinite dilution) ion association constant, $K_{\mathrm{A}}$, (details are given in ref. $\left.{ }^{23}\right)$. By using the literature value $\lambda_{\mathrm{Cl}^{-}}^{\infty}(298.15 \mathrm{~K})=76.35 \mathrm{~S} \cdot \mathrm{cm}^{2} \cdot \mathrm{mol}^{-1}$, the limiting molar conductivity was split into separate ionic contributions, $\lambda_{\mathrm{i}}^{\infty}$ , and then the values of limiting ionic conductivity were estimated for all cations. Consequently, the diffusion coefficients, $D_{i}^{\infty}$, as the characteristic properties of ionic trans- port, which are not affected by inter ionic interactions, were calculated by using the relation

$$
D_{i}^{\infty}=\frac{k \cdot T}{e_{o}\left|z_{i}\right| F} \lambda_{i}^{\infty}
$$

Values of $D_{i}^{\infty}$ for ILs cations, studied in ${ }^{6}$ at $298.15 \mathrm{~K}$ are presented in Figure 6 as a function of the number of $\mathrm{C}$ atoms in the alkyl side chain, together with the values that were obtained from MD simulations that were carried out at the same temperature. ${ }^{6}$

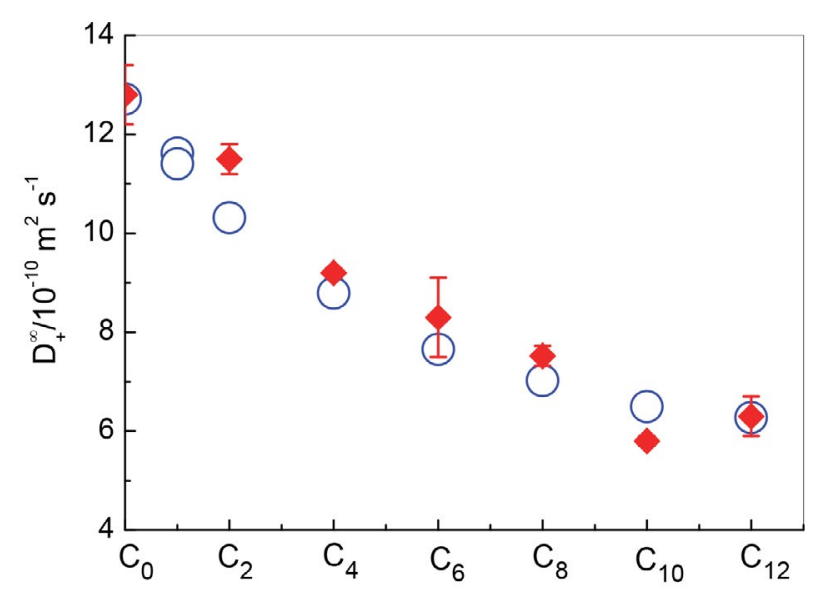

Figure 6. Diffusion coefficients of imidazolium based cations in water at $298.15 \mathrm{~K}$ as a function of the number of carbon atoms in the side chain: $O$ ) experiment; $\bullet$ ) MD simulations. Figure reproduced from ref. ${ }^{6}$ with permission from PCCP Owner Societies.

Again, the diffusion coefficient of $[\mathrm{mim}]^{+}$is only slightly lower from that for $\mathrm{Na}^{+}, D_{\mathrm{Na}^{+}}^{\infty}(298.15 \mathrm{~K})=13.3$. $10^{-10} \mathrm{~m}^{2} \cdot \mathrm{s}^{-1}$, and $D_{+}^{\infty}$ is decreasing with increasing length
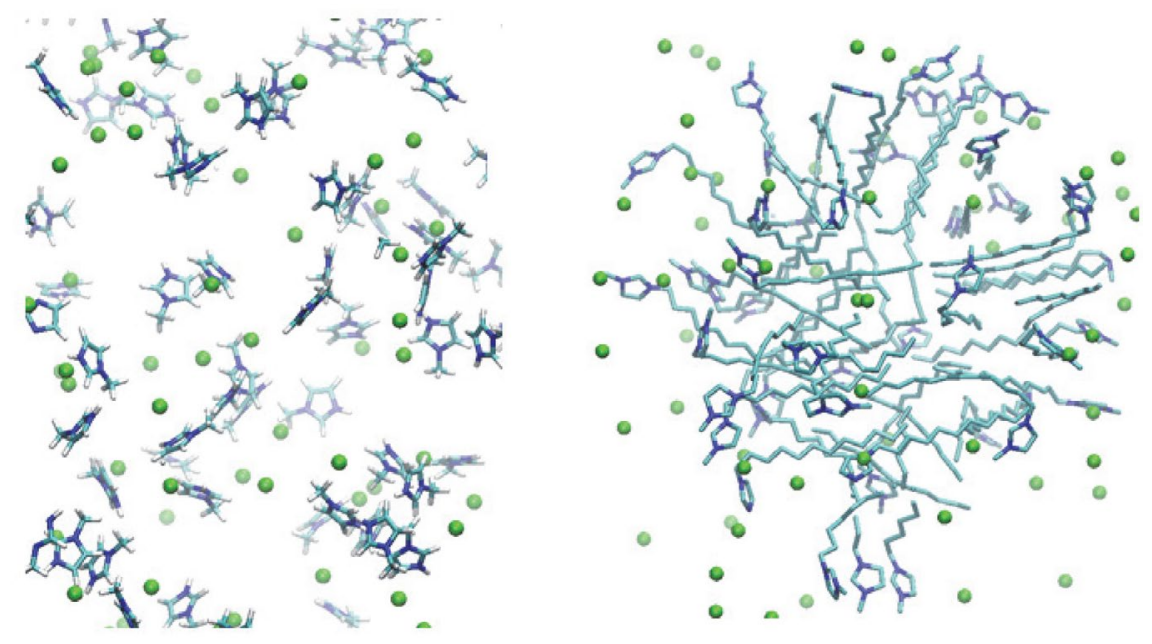

Figure 7. Representative structures of $[\mathrm{mim}] \mathrm{Cl}$ in solution (left hand side) and $\left[\mathrm{C}_{12} \mathrm{mim}\right] \mathrm{Cl}$ (right hand side) taken from equilibrated $\mathrm{MD}$ simulations at very high IL concentrations $\left(1.0 \mathrm{M}\right.$ and $1.2 \mathrm{M}$, respectively). It can be clearly seen that $\left[\mathrm{C}_{12} \mathrm{mim}\right] \mathrm{Cl}$ forms micelles in contrast to [mim] [Cl], which remained dispersed. The display of water and hydrogens was omitted for clarity. Color code: $\mathrm{C}=\mathrm{cyan}, \mathrm{N}=$ blue and $\mathrm{Cl}=$ green. Figure reproduced from ref. ${ }^{6}$ with permission from PCCP Owner Societies. 
of alkyl chain (Figure 6), but not linearly with the growing number of $\mathrm{C}$ atoms in the side alkyl chain as it has been also obtained by MD simulations. ${ }^{6,24}$ In addition, it was found that the aggregation tendency of cations with long alkyl chains at higher IL concentrations impedes their diffusivity.

This assumption was confirmed by the results of MD simulations at high concentrations. It was observed that within less than $1 \mathrm{~ns}\left[\mathrm{C}_{12} \mathrm{mim}\right]^{+}$cations formed micelles that remained stable throughout the rest of the simulations as expected. In contrast, $[\mathrm{mim}]^{+}$cations remained dispersed in water and did not show any signs of aggregation. The cation distribution in water is visualized for these two cases in Figure $7 .^{6}$ The reduction of $\left[\mathrm{C}_{12} \mathrm{mim}\right]^{+}$diffusivity is thus also a result of the cation aggregation. $\left[\mathrm{C}_{12} \mathrm{mim}\right]^{+}$ cations diffuse as members of these micelle aggregates, which move much slower through the solvent than single cations because of the large aggregate sizes.

Recently, for $\left[\mathrm{C}_{2} \mathrm{mim}\right] \mathrm{Cl},\left[\mathrm{C}_{4} \mathrm{mim}\right] \mathrm{Cl},\left[\mathrm{C}_{6} \mathrm{mim}\right] \mathrm{Cl}$ and $\left[\mathrm{C}_{8} \mathrm{mim}\right] \mathrm{Cl}$ the data on conductivity of concentrated aqueous solutions at $298.15 \mathrm{~K}$, presented in Figure 8, were published. ${ }^{25}$ To reproduce this type of concentration dependence, the empirical Casteel-Amis four-parameter equation ${ }^{26}$ is widely used. Generally, data fitting is carried out on the molality scale. For the present systems, Castel-Amis equation can be reasonably applied in the mole-fraction scale of IL, $x_{\mathrm{IL}}$, that is

$$
\begin{aligned}
& \kappa=\kappa_{\max }\left(\frac{x_{\mathrm{IL}}}{x_{\mathrm{IL}, \max }}\right)^{n} \exp \left[m\left(x_{\mathrm{IL}}-x_{\mathrm{IL}, \text { max }}\right)^{2}-\right. \\
& \left.-n\left(\frac{x_{\mathrm{IL}}-x_{\mathrm{IL}, \text { max }}}{x_{\mathrm{IL}, \text { max }}}\right)\right]
\end{aligned}
$$

where, $\kappa_{\max }$ is the highest electrical conductance for a given mixture, $x_{\mathrm{IL}, \max }$ is the mole fraction of IL in which the electrical conductivity of the mixture at a given temperature shows a maximum, and $n$ and $m$ are parameters of the fit. Casteel-Amis parameters are given in Table S1 in the Supplementary data and fitted conductivity values are graphically presented in Figure 8. In the inset of Figure 8, the values for $\mathrm{NaCl}$ solutions are added for comparison.

Evidently, in all the here presented systems, conductivity increases sharply in dilute region, due to the increased number of free ions in solutions. But with the addition of ILs, it reaches maximum at nearly the same mole fraction, i.e. at around $x_{\mathrm{IL}} \cong 0.05$, and then it decreases. This trend is assumed to be the result of the competition between the increasing number of free ions available to contribute to the conductivity and the increasing system viscosity, impeding ion mobility. And here, the conductivity decreases also with the increasing alkyl chain length of the cation, whereas the viscosity is higher for ILs with a longer side chain. As ions are added to the system ion diffusion is hindered by increased viscous forces, resulting in a decrease in ion mobility and, thus, diffusion.

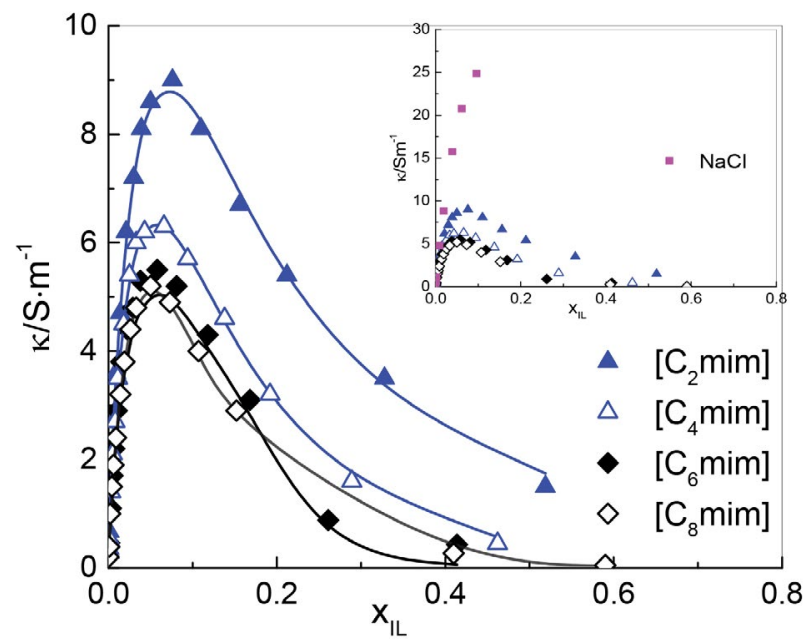

Figure 8. Specific conductivity, $\kappa$, of some imidazolium based ILs chlorides at $298.15 \mathrm{~K}$ in water as drown from the literature data. ${ }^{25}$ Inset: $\kappa$ of some ILs chlorides and $\mathrm{NaCl}$ at $298.15 \mathrm{~K}$ in water. ${ }^{27}$ Symbols represent experimental values and lines the CasteelAmis-type fitting (Eq. (2)) of the experimental data with parameters reported in Table S1 of the Supplementary data.

Actually, this behavior is not new - the same was observed for "common simple" electrolytes, where the maximum often was not reached due to limited solubility, as it is demonstrated here for $\mathrm{NaCl}$ in water (inset in Figure 8). And thus, ILs could be very helpful at studying the concentrated electrolyte solutions, where the reliable theories are still lacking.

Ion association. For in the ref. ${ }^{6}$ studied imidazolium based ILs in water it was found, that $K_{\mathrm{A}}$ values are small $\left(\sim 2.5 \leq K_{\mathrm{A}} \leq \sim 6\right)$ but distinctly higher than obtained with the same model recently for alkali metal halides in water. ${ }^{28}$ For $\left.\left[\mathrm{C}_{4} \mathrm{mim}\right]^{+},\left[\mathrm{C}_{6} \mathrm{mim}\right]^{+},\right]^{+}$and $\left[\mathrm{C}_{12} \mathrm{mim}\right]^{+}$, the binding free energies with $\mathrm{Cl}^{-}, \Delta G_{\text {bind }}^{\mathrm{MD}}$, were obtained also from

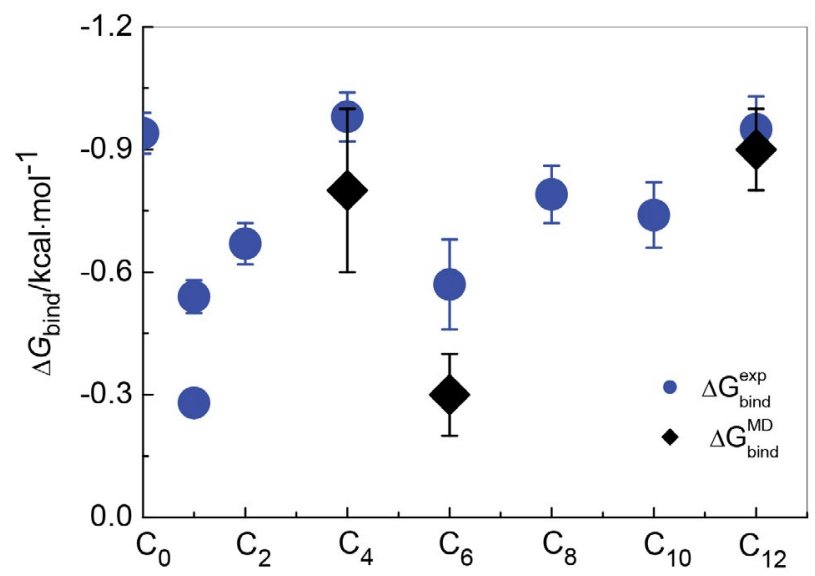

Figure 9. Comparison of binding free energies for imidazolium based chlorides in water as a function of the number of $\mathrm{C}$ atoms in the side alkyl chain as obtained from conductivity experiment, $\Delta G_{\text {bind }}^{\exp }$, and from MD simulations, $\Delta G_{\text {bind. }}^{\mathrm{MD}}$. Adopted from ref. ${ }^{6}$ with permission from PCCP Owner Societies. 
MD simulations, using thermodynamic integration as specified in ref. ${ }^{6}$ From the measured values of $K_{\mathrm{A}}$, binding free energies were calculated using the relation $\Delta G_{\text {bind }}^{\text {exp }}=-\mathrm{RT} \cdot \ln K_{A}$. In Figure 9, the comparison of $\Delta G_{\text {bind }}^{\exp }$ and $\Delta G_{\text {bind }}^{\mathrm{MD}}$, is shown. Evidently, results from MD simulations are in reasonable agreement with the experiment.

Despite the fact that conductivity measurements of dilute electrolyte solutions are probably still the most accurate route to ion-pair association constant, $K_{\mathrm{A}}$, at least for symmetrical electrolytes, ${ }^{23}$ such studies can determine only the overall association and thus yield little information on the nature of the aggregate(s) formed, while conventional spectroscopic techniques, like NMR or Raman spectroscopy, generally detect only contact CIPs. ${ }^{29}$ On the other hand, dielectric relaxation spectroscopy (DRS) is sensitive to all ion-pair types and allows their identifica-

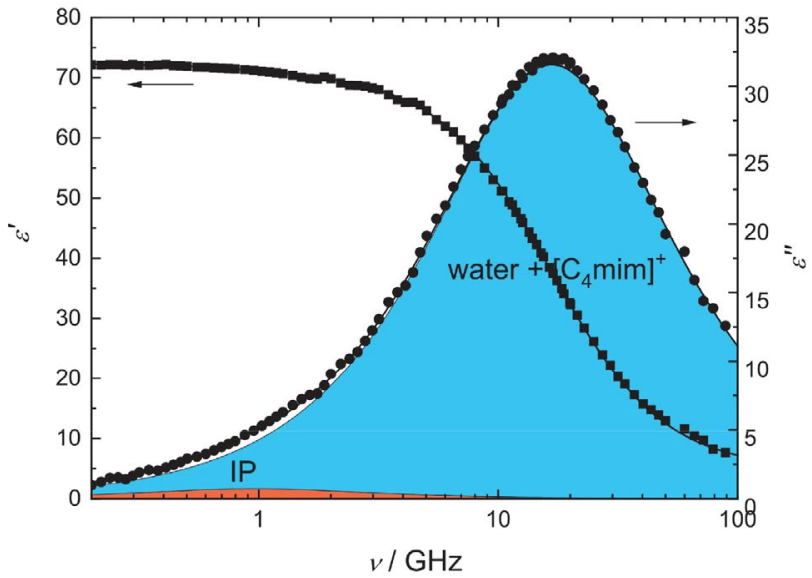

Figure 10. Relative permittivity, $\varepsilon^{\prime}(v)(\mathbf{\square})$ and dielectric loss, $\varepsilon^{\prime \prime}(v)$ $(\bullet)$ spectrum of a representative $\left[\mathrm{C}_{4} \mathrm{mim}\right] \mathrm{Cl}$ solution in water $(c=$ $0.4618 \mathrm{~mol} \mathrm{dm}^{-3}$ ) at $298.15 \mathrm{~K}$. Symbols represent experimental data, lines show the corresponding fit, and the shaded areas indicate the contributions of the individual processes to $\varepsilon$ " $(v)$. Adopted from ref. ${ }^{32}$ with permission from PCCP Owner Societies. tion and quantification provided reasonably accurate dipole moments, $\mu_{\mathrm{i}}$, of the species formed are available or can be calculated. ${ }^{30,31}$ Having a look on DRS spectra for $\left[\mathrm{C}_{4} \mathrm{mim}\right] \mathrm{Cl}$ solution in water (Figure 10) we can see an area, which corresponds to ion pairs (IP). ${ }^{32}$

Thus, MD simulations and experiments reveal that the association of investigated ILs as model 1,1 electrolytes in water solutions is weak but evidently dependent on the molecular structure (alkyl chain length), which also strongly affects the mobility of cations.

\section{2. Ionic liquids in Non-aqueous Solutions}

Pure ILs are usually quite viscous and less conductive, whereas the mixing of ILs with molecular liquids (cosolvents) causes a significant decrease of viscosity and a sharp increase of conductivity. ${ }^{1-14}$ A huge number of investigations on conductivity of mixtures of ILs with molecular solvents is available in the literature. Surprisingly, despite the large practical interest for such systems, systematic studies of the transport properties of binary mixtures of ILs and cosolvents in a broad concentration range - from diluted solutions to pure ILs - are still scarce. Thus, in this paper we will focus our attention mainly on those imidazolium based ILs, which are also well investigated in a broader concentration range in aqueous and non-aqueous solutions and thus the comparison of their properties is possible.

Diluted solutions. In Figure 11 a) the molar conductivity of $\left[\mathrm{C}_{4} \mathrm{mim}\right] \mathrm{Cl}$ in acetonitrile $(\mathrm{AN}),{ }^{32}$ methanol $(\mathrm{MetOH})^{5}$ and dimethyl sulfoxide (DMSO) $)^{5}$ are presented together with values in water. ${ }^{6}$ Evidently, the mobility of $\left[\mathrm{C}_{4} \mathrm{mim}\right]^{+}$, as indicated by the ionic limiting conductivity $\lambda_{\left[\mathrm{C}_{4} \mathrm{mim}\right]^{+}}^{\infty}$ and the diffusion coefficients $D_{\left[\mathrm{C}_{4} \mathrm{mim}\right]^{+}}^{\infty}$, is decreasing with increasing viscosity of the solvents (Table $1)$.

In Figure $11 \mathrm{~b})$, the molar conductivity of $\left[\mathrm{C}_{4} \mathrm{mim}\right] \mathrm{Cl},{ }^{32}\left[\mathrm{C}_{4} \mathrm{mim}\right] \mathrm{BF}_{4}{ }^{4}$ and - for comparison - tetra-
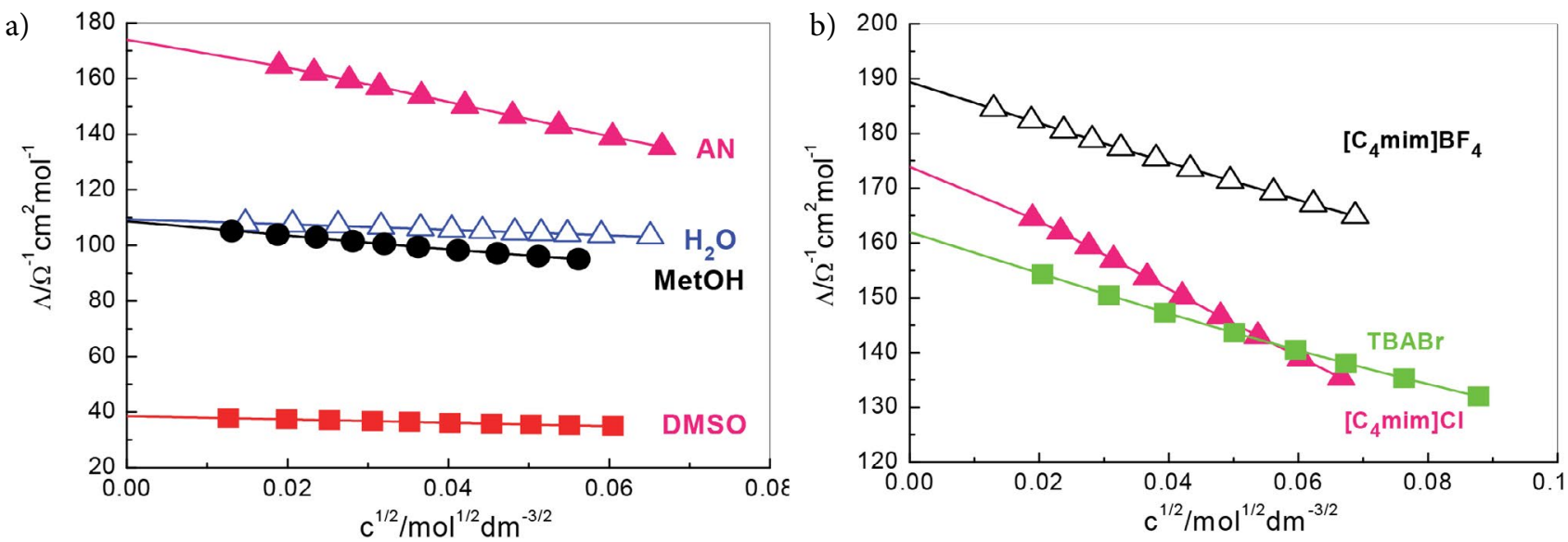

Figure 11. Molar conductivity of a) $\left[\mathrm{C}_{4} \mathrm{mim}\right] \mathrm{Cl}$ in $\mathrm{AN},{ }^{32}$ water, ${ }^{6} \mathrm{MetOH}^{5}$ and $\mathrm{DMSO}^{5}$ and b) $\left[\mathrm{C}_{4} \mathrm{mim} \mathrm{Cl}^{32}\left[\mathrm{C}_{4} \mathrm{mim}^{3} \mathrm{BF}_{4}{ }^{4}\right.\right.$ and $\mathrm{TBABr}$ in $\mathrm{AN}^{33}$ at $298.15 \mathrm{~K}$; symbols denote experiment and lines lcCM calculations. 
Table 1. Literature data on molar limiting conductivity, $\Lambda^{\infty}$, and association constants, $K_{\mathrm{A}}$, for $\left[\mathrm{C}_{4} \mathrm{mim}\right] \mathrm{Cl}$ and $\left[\mathrm{C}_{4} \mathrm{mim}\right] \mathrm{BF}{ }_{4}$ in water, DMSO, AN, DMF, MetOH and DCM at $298.15 \mathrm{~K}$ as obtained from lcCM model. Where possible, ionic limiting conductivity $\lambda_{\left[\mathrm{C}_{4} \text { mim] }\right.}^{\infty}{ }^{+}$and the (average) values of the diffusion coefficients $D_{\left[\mathrm{C}_{4} \mathrm{mim}\right]}^{\infty}$ are given. $\varepsilon$ and $\eta$ denote dielectric constant and viscosity of solvents, respectively. ${ }^{\mathrm{a}}$

\begin{tabular}{|c|c|c|c|c|c|c|c|c|c|}
\hline & \multirow[t]{2}{*}{$\varepsilon$} & \multirow[t]{2}{*}{$\eta$} & \multicolumn{2}{|c|}{$\Lambda^{\infty}$} & \multicolumn{2}{|c|}{$K_{\mathrm{A}}$} & \multicolumn{2}{|c|}{$\lambda_{\left[\mathrm{C}_{4} \text { mim }\right]^{+}}^{\infty}$} & \multirow{2}{*}{$D_{\left[\mathrm{C}_{4} \mathrm{mim}\right]}^{\infty}$} \\
\hline & & & $\mathrm{Cl}^{-}$ & $\mathrm{BF}_{4}^{-}$ & $\mathrm{Cl}^{-}$ & BF4 $^{-}$ & $\mathrm{Cl}^{-}$ & $\mathrm{BF}_{4}^{-}$ & \\
\hline $\mathrm{H}_{2} \mathrm{O}$ & 78.36 & 0.8903 & $\begin{array}{l}109.34^{\mathrm{b}} \\
108.64^{\mathrm{c}}\end{array}$ & & $\begin{array}{l}5.2^{\mathrm{b}} \\
6.2^{\mathrm{c}}\end{array}$ & & $\begin{array}{l}32.99^{\mathrm{b}} \\
32.29^{\mathrm{c}}\end{array}$ & & 8.69 \\
\hline DMSO & 46.52 & 1.9946 & $38.53^{\mathrm{d}}$ & $41.51^{\mathrm{d}}$ & $13.4^{\mathrm{d}}$ & $4.6^{\mathrm{d}}$ & $14.89^{\mathrm{d}}$ & $14.53^{\mathrm{d}}$ & 3.92 \\
\hline DMF & 36.81 & 0.845 & & $89.83^{\mathrm{e}}$ & & $10.6^{\mathrm{e}}$ & & & \\
\hline AN & 35.96 & 0.3413 & $173.91^{\mathrm{c}}$ & $\begin{array}{l}189.29^{\mathrm{f}} \\
190.37^{\mathrm{g}}\end{array}$ & $63.7^{\mathrm{c}}$ & $\begin{array}{l}15.7^{\mathrm{f}} \\
17.8^{\mathrm{g}}\end{array}$ & $81.55^{\mathrm{c}}$ & $81.81^{\mathrm{f}}$ & 21.75 \\
\hline $\mathrm{MetOH}$ & 32.63 & 0.5438 & $108.64^{\mathrm{d}}$ & $\begin{array}{l}121.84^{\mathrm{d}} \\
128.4^{\mathrm{h}}\end{array}$ & $15.5^{\mathrm{d}}$ & $\begin{array}{l}37.7^{\mathrm{d}} \\
57.5^{\mathrm{h}}\end{array}$ & $56.25^{\mathrm{d}}$ & & 14.98 \\
\hline DCM & 8.82 & 0.415 & & $161.08^{\mathrm{i}}$ & & $479^{\mathrm{i}}$ & & & \\
\hline
\end{tabular}

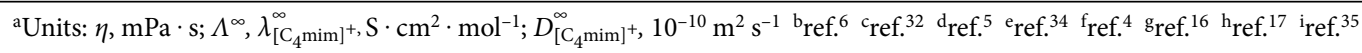

butylammonium bromide (TBABr) ${ }^{33}$ as "classical" electrolyte in AN are shown. While in water only weak association was observed $\left(\mathrm{K}_{\mathrm{A}} \cong 5-6\right)$ for $\left[\mathrm{C}_{4} \mathrm{mim}\right] \mathrm{Cl}$, it is expectedly more expressed in solvents with lower dielectric constants, but evidently depends strongly also on the anion as can be seen in Table 1, where literature data of molar limiting conductivity, $\Lambda^{\infty}$, and association constants, $K_{\mathrm{A}}$, for $\left[\mathrm{C}_{4} \mathrm{mim}\right] \mathrm{Cl}$ and $\left[\mathrm{C}_{4} \mathrm{mim}\right] \mathrm{BF}_{4}$ in water, $\mathrm{DMSO}, \mathrm{AN}$, N,N-Dimethylformamide (DMF), MetOH and dichloromethane (DCM) at $298.15 \mathrm{~K}$ are gathered, as obtained from lcCM model. Where the value of the ionic limiting conductivity $\lambda_{\left[\mathrm{C}_{4} \mathrm{mim}\right]^{+}}^{\infty}$ is available, also the (average) values of the diffusion coefficient $D_{\left[\mathrm{C}_{4} \mathrm{mim}\right]^{+}}^{\infty}$ are listed.

Whereas values of $\Lambda^{\infty}$ are not very "sensitive" on the applied model for the analysis of conductivity data, the opposite is true for $K_{\mathrm{A}}$. Even more, $K_{\mathrm{A}}$ values are also slightly dependent on the set upper distance limit at which the ions are still treated as ion pairs. However, the abundant different interactions acting together in ILs make them very complex (Figure 2), so that it is not surprising that the dielectric constant is incapable to adequately model the solvent-solute interactions and has often failed in correlating solvent effects qualitatively and quantitatively. It is namely rather surprising, that $K_{\mathrm{A}}$ values for $\left[\mathrm{C}_{4} \mathrm{mim}\right] \mathrm{Cl}$ and $\left[\mathrm{C}_{4} \mathrm{mim}\right] \mathrm{BF}_{4}$ in $\mathrm{AN}$ and $\mathrm{MetOH}$ are different despite very similar dielectric constants of these two solvents. However, the obtained $K_{\mathrm{A}}$ values for $\left[\mathrm{C}_{4} \mathrm{mim}\right] \mathrm{BF}_{4}$ and $\left[\mathrm{C}_{4} \mathrm{mim}\right] \mathrm{Cl}$ in $\mathrm{AN}$ are in line with those reported for sodium tetraphenylborate $\left(K_{\mathrm{A}}=13.9\right.$ at $\left.298,15 \mathrm{~K}^{36}\right)$ and $\mathrm{TBABr}$ $\left(K_{\mathrm{A}}=27.5\right.$ at $\left.298.15 \mathrm{~K}^{33}\right)$.

Having a look on DRS spectra for the $\left[\mathrm{C}_{4} \mathrm{mim}\right] \mathrm{Cl}$ solution in AN (Figure 12) and in water (Figure 10) we can see an area, which corresponds to ion pairs (IP), and this area is much bigger in $\mathrm{AN}$ than in water. Thus, evidently the ion pair formation tendency is stronger in $\mathrm{AN}$ and the values of $K_{\mathrm{A}}$ obtained from conductivity data using lcCM model make sense. It could be again concluded that ILs in solutions behave as common ("classical") simple electrolytes, with more expressed ion association in solvents with lower dielectric constants.

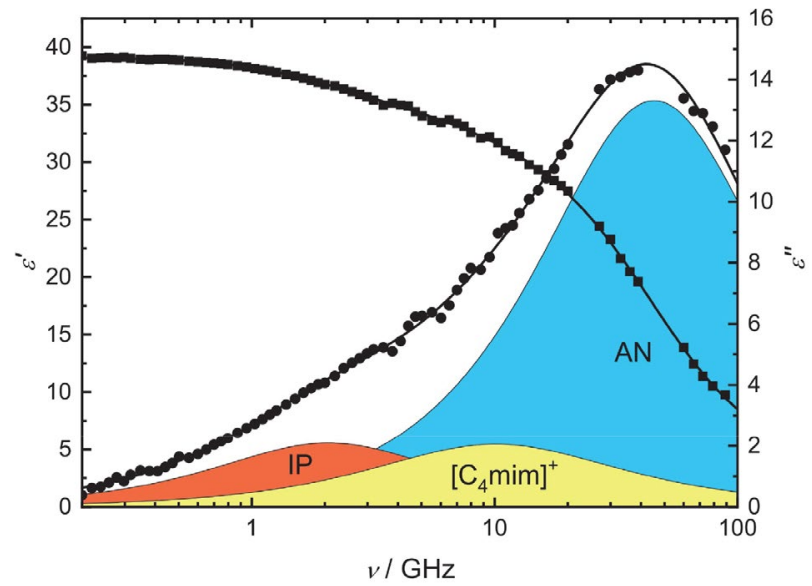

Figure 12. Relative permittivity, $\varepsilon^{\prime}(v)(\mathbf{\square})$ and dielectric loss, $\varepsilon^{\prime \prime}(v)$ $(\bullet)$ spectrum of a representative $\left[\mathrm{C}_{4} \mathrm{mim}\right] \mathrm{Cl}$ solution in $\mathrm{AN}(\mathrm{c}=$ $0.4658 \mathrm{~mol} \mathrm{dm}^{-3}$ ) at $298.15 \mathrm{~K}$. Symbols represent experimental data, lines show the corresponding fit, and the shaded areas indicate the contributions of the individual processes to $\varepsilon$ " $(v)$. Adopted from ref. ${ }^{32}$ with permission from PCCP Owner Societies.

Concentrated solutions. Despite still growing number of studies and reviews dealing with physicochemical properties of ILs in the pure state and of their mixtures with cosolvents, the systematic studies on transport properties covering entire miscibility range are still scarce. In Figure 13 a) some literature data on conductivity of concentrated solutions of $\left[\mathrm{C}_{4} \mathrm{mim}\right] \mathrm{BF}_{4}$ in $\mathrm{AN}, \mathrm{MetOH}, \mathrm{DMSO}, \mathrm{DCM}$, and propylene carbonate $(\mathrm{PC}, \eta=2.512 \mathrm{mPa} \cdot \mathrm{s}, \varepsilon=64.96$ 

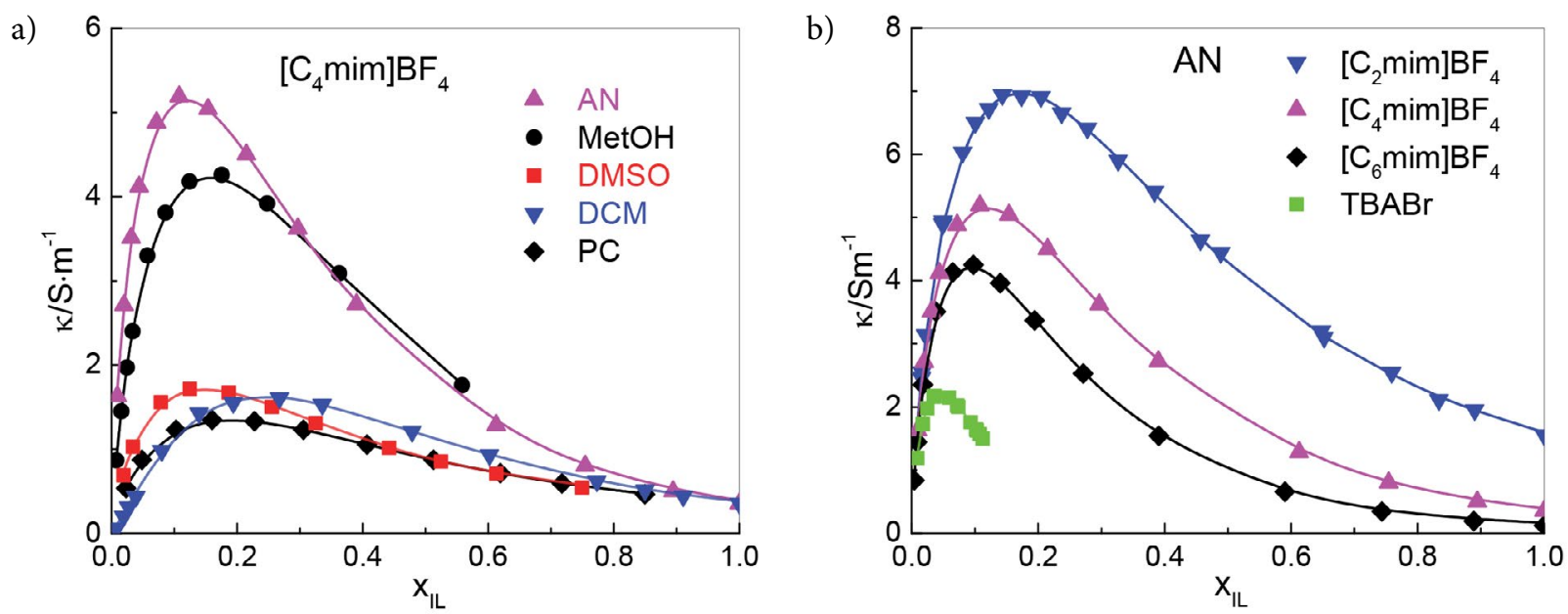

Figure 13. Specific conductivity, $\kappa$, of a) $\left[\mathrm{C}_{4} \mathrm{mim}\right] \mathrm{BF}_{4}$ in $\mathrm{AN},{ }^{37} \mathrm{MetOH},{ }^{37} \mathrm{DMSO},{ }^{37} \mathrm{DCM},{ }^{37}$ and $\mathrm{PC}^{37}$ and b) $\left[\mathrm{C}_{2} \mathrm{mim}\right] \mathrm{BF}_{4},{ }^{37}\left[\mathrm{C}_{4} \mathrm{mim}^{3} \mathrm{BF}_{4},{ }^{37}\left[\mathrm{C}_{6} \mathrm{mim}^{3}\right]\right.$ $\mathrm{BF}_{4}{ }^{37}$ and $\mathrm{TBABr}^{38}$ in $\mathrm{AN}$ at $298.15 \mathrm{~K}$ as a function of molar fraction of IL, $\mathrm{x}_{\mathrm{IL}}$. Symbols represent experimental values and lines the Casteel-Amistype fitting (Eq. (2)) of the experimental data with parameters reported in Table S1 of the Supplementary data.

at $298.15 \mathrm{~K}$ ) are presented as determined by Stoppa et al. ${ }^{37}$ Conductivity of three imidazolium based tetrafluoroborates in AN from the same paper are shown in Figure $13 \mathrm{~b}$ ) together with data on $\mathrm{TBABr}$ in $\mathrm{AN}^{38}$ for comparisons.

From Figure 13 it is evident that conductivity follows the typical pattern of concentrated electrolyte solutions, discussed already in paragraph 3.1. and presented in Figure 8 for aqueous solutions. ${ }^{6}$ After a rapid rise in the low concentration region, $\kappa$ passes through a well-defined maximum. As it follows from the data, presented in Figure $13 \mathrm{~b}$ ) and table S1 in Supplementary data, $\kappa$ for ILs in AN decreases with increasing alkyl chain length of the cation, as it has been observed also for the aqueous solutions of $\mathrm{IL}_{S}$, presented in Figure 8. Whereas in water solution the position of the conductivity maximum was more or less close to the $x_{\mathrm{IL}} \cong 0.05$, here the maximum is reached at higher concentration and it moves toward lower $\mathrm{x}_{\mathrm{IL}}$ with increasing length of the side alkyl chain of cation.

Figure 13 a) reveals clearly that $\kappa$ for $\left[\mathrm{C}_{4} \mathrm{mim}\right] \mathrm{BF}_{4}$ depends strongly on the solvent: when the viscosity increases $(\mathrm{AN}<\mathrm{MetOH}<\mathrm{DMSO}<\mathrm{PC}), \kappa$ decreases. But DCM does not follow this order: despite the fact that its viscosity is very low $(0.415 \mathrm{mPa}$ at $298.15 \mathrm{~K})$, the conductivity of $\left[\mathrm{C}_{4} \mathrm{mim}\right] \mathrm{BF}_{4}$ solutions in DCM is close to that in DMSO and PC with much higher solvent viscosity (Table
1). This behavior can be ascribed to higher ion association in DCM due to the lower dielectric constant. The value, obtained in diluted solutions by Borun and Bald ${ }^{35}\left(K_{\mathrm{A}}=\right.$ 479 at $298.15 \mathrm{~K}$, Table 1) confirms strongly this assumption. Even more - also in other solvents the decrease of conductivity after the maximum could be ascribed to stronger ion association. Unfortunately, there is no theory to describe this behavior.

\section{3. Surface Active Ionic Liquids}

Aggregation/micellization in aqueous solutions. As it is already presented in Figure 7, it was confirmed by MD simulations that $\left[\mathrm{C}_{12} \mathrm{mim}\right] \mathrm{Cl}$ forms micelles at higher concentrations. Even more, the great potential of surface active ionic liquids (SAILs) at investigating the thermodynamics of micellization process in solutions due to possible variations in the structure of cations, side chain length and counter ions has been demonstrated recently. 818,19 , The systems studied recently by Šarac et $\mathrm{al}^{8}{ }^{8}$ are presented in Figure 14.

It was found that in many ways the behavior of SAILs is identical to that observed for "classical" cationic surfactants: the critical micelle concentration is decreasing with the length of the hydrophobic chain (Figure 15) and ex-<smiles>CC(=O)[O-]</smiles>

a)<smiles>O=C([O-])C(F)(F)F</smiles>

c)<smiles>O=C([O-])c1ccccc1O</smiles>

d)<smiles>CS(=O)(=O)[O-]</smiles>

e)<smiles>Cc1ccc(S(=O)(=O)[O-])cc1</smiles>

g)

Figure 14. Structures of investigated systems in ref. $\left.{ }^{8}: \mathrm{a}\right) \mathrm{n}=9\left(\left[\mathrm{C}_{10} \mathrm{mim}\right]\right), \mathrm{n}=11\left(\left[\mathrm{C}_{12} \mathrm{mim}\right]\right), \mathrm{n}=13\left(\left[\mathrm{C}_{14} \mathrm{mim}\right]\right)$ and $\mathrm{n}=15\left(\left[\mathrm{C}_{16} \mathrm{mim}\right]\right)$ cations in $\left[\mathrm{C}_{\mathrm{N}} \mathrm{mim}\right] \mathrm{Cl}$ and b) $\mathrm{OAc}^{-}$, c) $\mathrm{TFA}^{-}$, d) $\mathrm{Sal}^{-}$, e) $\mathrm{OMs}^{-}$, f) $\mathrm{OTf}^{-}$, and g) OTs ${ }^{-}$anions in $\left[\mathrm{C}_{12} \mathrm{mim}\right] \mathrm{X}$ systems. Figure reproduced from ref. ${ }^{8}$ with permission from Elsevier. 


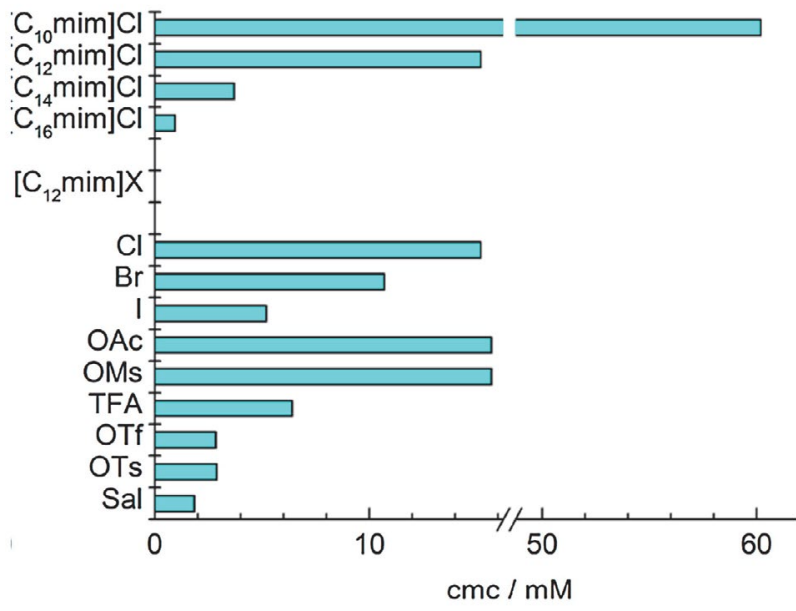

Figure 15. Critical micelle concentrations, $\mathrm{cmc}$, for all systems studied in ref. ${ }^{8}$ at $298.15 \mathrm{~K}$. Figure reproduced from ref. ${ }^{8}$ with permission from Elsevier.

presses a minimum in the temperature dependence, but depends strongly also on the counter ion. ${ }^{8}$

In general, the micellization process for SAILs is as usual endothermic at low temperatures and exothermic at high temperatures, but it was verified that counter ions play an extremely important role. ${ }^{8}$ Even more, it was confirmed, that the hydrophobicity of counter ions evidently contributes to the heat capacity change and the water accessible surface area removal upon burial of non-polar group from the contact with water during the micellization process.

The main driving force for the formation of micelles is presumably the apparent disaffinity of water for the nonpolar (interacting) surfaces known as the hydrophobic effect. The parameter that illustrates this effect is the heat capacity of micellization, $\Delta_{\mathrm{M}} c_{\mathrm{p}}^{0}$, which is always highly negative and can be ascribed to the removal of water molecules from contact with nonpolar surface area upon micelle formation. ${ }^{39}$ By modeling the micellization processes as a transfer of surfactant molecules into the micellar phase, the heat capacity can be expressed in terms of the change of water accessible nonpolar and polar surface areas, as derived by Spolar et al. ${ }^{40}$ from the protein folding studies:

$$
\begin{aligned}
& \Delta_{M} c_{p}^{o}\left(\mathrm{~J} \cdot \mathrm{K}^{-1} \cdot \mathrm{mol}^{-1}\right)=-1.34( \pm 0.33) \cdot \Delta \mathrm{A}_{\mathrm{np}}\left(\stackrel{0}{\mathrm{~A}^{2}}\right)+ \\
& +0.59( \pm 0.17) \cdot \Delta \mathrm{A}_{\mathrm{p}}\left(\mathrm{A}^{2}\right)
\end{aligned}
$$

where $\Delta \mathrm{A}_{\mathrm{p}}$ stands for the loss of water accessible polar and $\Delta \mathrm{A}_{\mathrm{np}}$ for nonpolar surface area upon protein folding. Because the hydrophilic head groups of non-ionic surfactants remain hydrated upon micelle formation, the "theoretical" contribution of water accessible nonpolar surface area change to the heat capacity change upon micelle formation, $\Delta_{\mathrm{M}} c_{\mathrm{p}}^{0}\left(\mathrm{th}_{\mathrm{np}}\right)$, can be assumed to reflect only the change in exposure of the hydrophobic tails to water. Consequently, the Eq. (3) is reduced to

$$
\begin{aligned}
\Delta_{M} c_{p}^{o}\left(\mathrm{th}_{\mathrm{np}}\right)\left(\mathrm{J} \cdot \mathrm{K}^{-1} \cdot \mathrm{mol}^{-1}\right)= & -1.34(\underset{\mathrm{o}}{ \pm 0.33)} . \\
& \cdot \Delta \mathrm{A}_{\mathrm{np}}\left(\mathrm{A}^{2}\right)
\end{aligned}
$$

This approach turned out as useful for a series of non-ionic surfactants. ${ }^{41,42}$

According to Richards ${ }^{43}$ water accessible surface area of a methylene group is $30 \AA^{2}$ and $88 \AA^{2}$ for a methyl group. Thus, $\Delta \mathrm{A}_{\mathrm{np}}$ of the hydrophobic tails of the surfactants investigated in ref. ${ }^{8}$ is $358,418,478$ and $538 \AA^{2}$ for the $\mathrm{C}_{10}, \mathrm{C}_{12}, \mathrm{C}_{14}$ and $\mathrm{C}_{16}$ alkyl chain, respectively, giving the values of $\Delta_{\mathrm{M}} c_{\mathrm{p}}^{0}\left(\mathrm{th}_{\mathrm{np}}\right)=-479,-560$, -640 and $-720 \mathrm{~J} \cdot \mathrm{K}^{-1} \cdot \mathrm{mol}^{-1}$ for the same order of alkyl chains. Comparison of $\Delta_{\mathrm{M}} c_{\mathrm{p}}^{0}\left(\mathrm{th}_{\mathrm{np}}\right)$, estimated by Eq. (4) with $\Delta_{\mathrm{M}} c_{\mathrm{p}}^{0}$ (exp), as illustrated in Figure 16 a), reveals that there is an evident discrepancy between $\Delta_{\mathrm{M}} c_{\mathrm{p}}^{0}$ $\left(\mathrm{th}_{\mathrm{np}}\right)$ and $\Delta_{\mathrm{M}} c_{\mathrm{p}}^{0}$ (exp). This discrepancy was explained in two ways:
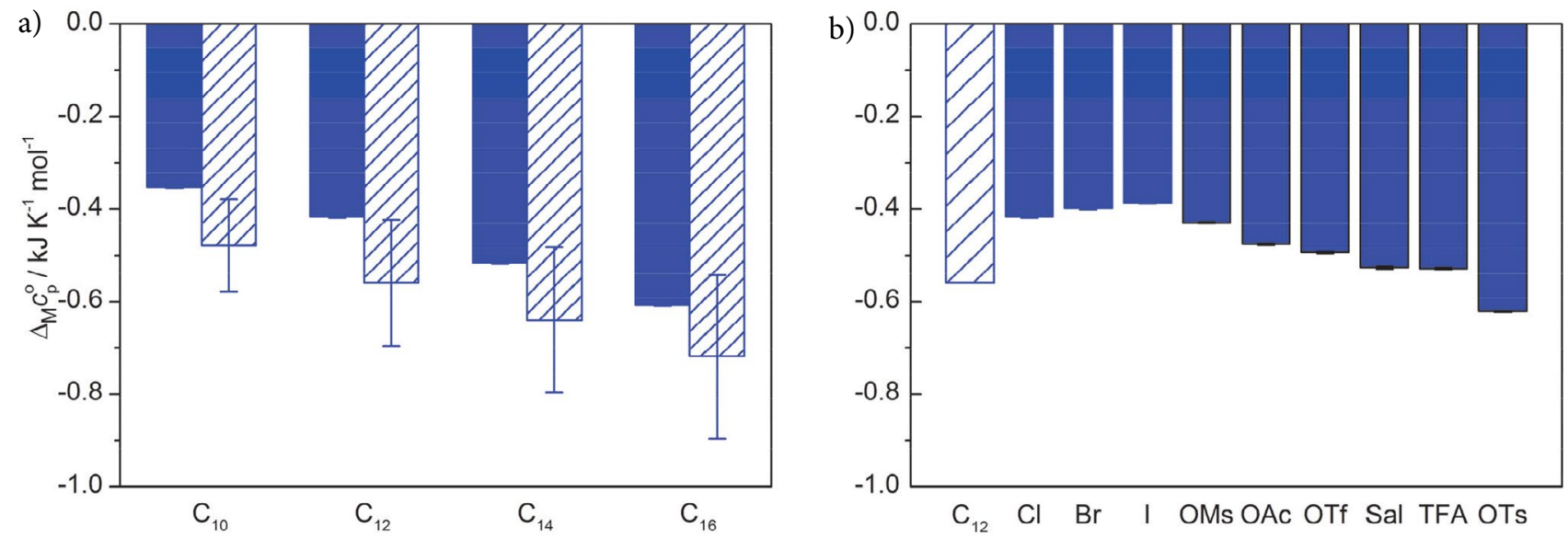

Fig. 16. Comparison of theoretical (shaded) and experimental (full columns) values of heat capacity changes upon micllization process, $\Delta_{\mathrm{M}} c_{\mathrm{p}}^{0}$, for a) $\left[\mathrm{C}_{\mathrm{n}} \mathrm{mim}\right] \mathrm{Cl}$ and $\left.\mathrm{b}\right)\left[\mathrm{C}_{12} \mathrm{mim}\right] \mathrm{X}$. Figure reproduced from ref. ${ }^{8}$ with permission from Elesevier. 
a) It can be assumed that there are still water molecules in the interior of the micelle upon micellization and thus the $\Delta \mathrm{A}_{\mathrm{np}}$ estimated by the approach of Richards ${ }^{43}$ mentioned above is overestimated. That is, the "real" $\Delta \mathrm{A}_{n p}$ is smaller than that according to Richards.

b) The Eq. (4) holds well for non-ionic surfactants, ${ }^{41,42}$ but it probably is not valid for ionic surfactants. Positive contribution of the removal of water accessible polar surface area to the heat capacity change of micellization should also be considered and cannot be neglected, consistent with the findings for the heat capacity change upon protein folding. ${ }^{40}$

The influence of counterion on $\Delta_{\mathrm{M}} c_{\mathrm{p}}^{0}$ for $\left[\mathrm{C}_{12} \mathrm{mim}\right] \mathrm{X}$ systems ${ }^{8}$ is illustrated in Figure $16 \mathrm{~b}$ ). For $\left[\mathrm{C}_{12} \mathrm{mim}\right] \mathrm{Cl}$, $\left[\mathrm{C}_{12} \mathrm{mim}\right] \mathrm{Br}$ and $\left[\mathrm{C}_{12} \mathrm{mim}\right] \mathrm{I}$ it is obvious that the difference between $\Delta_{\mathrm{M}} c_{\mathrm{p}}^{0}(\exp )$ and $\Delta_{\mathrm{M}} c_{\mathrm{p}}^{0}\left(\mathrm{th}_{\mathrm{np}}\right)$ increases along with an increase in the size of the anion. It is plausible to conjecture that the removal of water accessible polar surface area also increases along with an increase in the size of counter ion binding onto the micelle but it can be concluded that the $\Delta \mathrm{A}_{\mathrm{p}}$ part here cannot be neglected or/and that the hydrophobic parts of counter ions are incorporated in the micelles. In this case the contribution to the $\Delta_{\mathrm{M}} c_{\mathrm{p}}^{0}$ of the removal of the hydrophobic part of counterion from the contact with water after micellization can be assumed. Thus, the "hydrophobic" anions $\left(\mathrm{OTs}^{-}, \mathrm{OTf}^{-}, \mathrm{TFA}^{-}\right.$and $\mathrm{Sal}^{-}$) can be partially incorporated in the micelle and therefore the hydrophobic part of the anion can contribute to the $\Delta \mathrm{A}_{\mathrm{np}}$. The incorporation of counterions was already confirmed for $\left[\mathrm{C}_{16} \mathrm{mim}\right] \mathrm{OTs}$ by Singh et al. using various methods ${ }^{44}$ and for $\left[\mathrm{C}_{12}\right.$ mim] OTf by DRS. ${ }^{45}$

Recently, it was demonstrated on the dodecyltrimethylammonium chloride (DTACl) in the $0.01 \mathrm{M}$ solutions of sodium ortho- (o- $\mathrm{HBz}^{-}$, denoted previously as $\left.\mathrm{Sal}^{-}\right)$, meta$\left(m-\mathrm{HBz}^{-}\right)$, and para- hydroxybenzoate $\left(p-\mathrm{HBz}^{-}\right)$that even small changes in the structure of anion of the added salt, such as the position of the substituent on an aromatic ring, considerably influence the micellization process. ${ }^{46} \mathrm{Howev-}$ er, it should be kept in mind, that the micellization of DTACl in that case was studied in the presence of $\mathrm{NaCl}$, which also considerably affects the self-aggregation process. ${ }^{47}$ To prove the influence of isomerism of counterions on micellization of surfactant in water without any added compound the study of micellization of $\left[\mathrm{C}_{12} \mathrm{mim}\right] \mathrm{o}-\mathrm{HBz},\left[\mathrm{C}_{12} \mathrm{mim}\right]$ $m-\mathrm{HBz},\left[\mathrm{C}_{12} \mathrm{mim}\right] p-\mathrm{HBz}$ together with the benzoate salt $\left(\left[\mathrm{C}_{12} \mathrm{mim}\right]\right) \mathrm{HBz}$ (Figure 17) was carried out recently. ${ }^{19}$

It was found that the temperature dependence of $\mathrm{cmc}$ shows a nearly U-shaped form (Figure $18 \mathrm{a}$ )) but is strongly dependent on the presence and position of the $-\mathrm{OH}$ group in the counterion. The micellization process is endothermic at low temperatures and becomes exothermic at higher temperatures - a phenomenon usual for ionic surfactants - for all here investigated systems, only for $\left[\mathrm{C}_{12} \mathrm{mim}\right] \mathrm{o}$-HB it turned out that the micellization is exothermic in the whole investigated temperature range. It is namely well-known that $o-\mathrm{HBz}^{-}$provokes the formation of more compact elongated micelles by stronger interaction of $o-\mathrm{HBz}^{-}$with surfactant molecule and its subsequent incorporation resulting in the highest exothermicity of micellization process in the case of $o-\mathrm{HBz}^{-}$. More details are available in ref. ${ }^{19}$

Aggregation in non-aqueous solutions. Whereas the aggregation behavior of SAILs in aqueous solutions is relatively well investigated and understood, studies on the aggregation of SAILs in non-aqueous solvents are scarce although they are very important in many applications. Recently, the aggregation behavior and related physiochemical properties of $\left[\mathrm{C}_{12} \mathrm{mim}\right] \mathrm{Br}$ in DMSO, AN, DMF and formamide (FA) were investigated by conductivity and density measurements. ${ }^{20}$ It turned out that the aggregate formation in non-aqueous solvents is not as favored as in water, which is actually similar to the behavior observed for some conventional ionic surfactants by Ray. ${ }^{48}$ The critical aggregation concentration, cac, as a function of the empirical parameters of solvent polarity $E_{T}^{N}(30)^{49}$ is presented in Figure 19.

a)

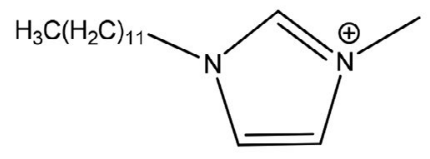

b)

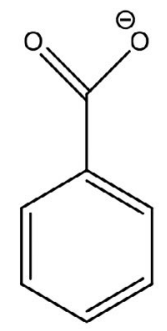

c)

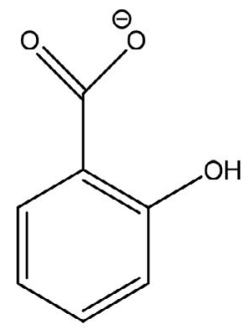

d)

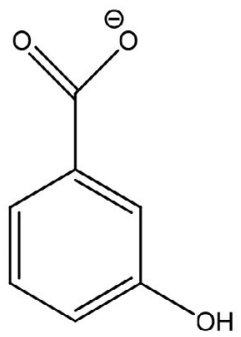

e)

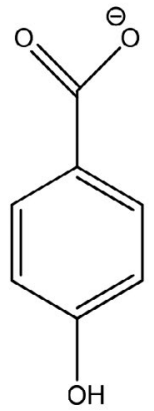

Figure 17. Structures of investigated systems: a) $\left[\mathrm{C}_{12} \mathrm{mim}\right]^{+}$; b) Bz ${ }^{-}$c) $o-\mathrm{HBz}^{-}$; d) $m-\mathrm{HBz}^{-}$e) $p-\mathrm{HBz}^{-}$. Figure reproduced from ref. ${ }^{19}$ with permission from Elsevier. 

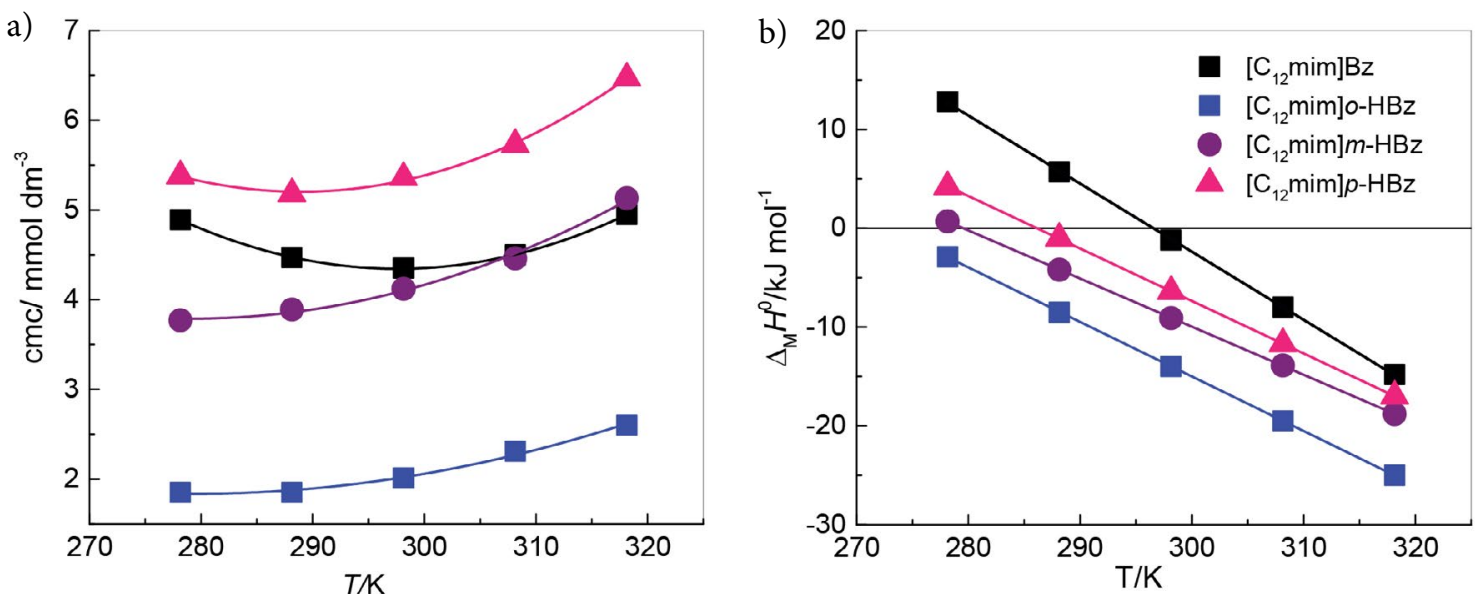

Figure 18. Temperature dependence of a) critical micelle concentration, $\mathrm{cmc}$, and b) the standard enthalpy o micellization, $\Delta_{\mathrm{M}} \mathrm{H}^{0}$ for [ $\left.\mathrm{C}_{12} \mathrm{mim}\right] \mathrm{HBz}$, $\left[\mathrm{C}_{12} \mathrm{mim}\right] \mathrm{o}-\mathrm{HBz},\left[\mathrm{C}_{12} \mathrm{mim}\right] \mathrm{m}-\mathrm{HBz}$ and $\left[\mathrm{C}_{12} \mathrm{mim}\right] p-\mathrm{HBz}$ in water. Solid lines represent in a) the corresponding polynomial fits, $\mathrm{cmc}=\mathrm{A}+\mathrm{B} T+\mathrm{CT} T^{2}$ (coefficients are given in Table S2 in Supplementary data); b) linear fits. Figure reproduced from ref. ${ }^{19}$ with permission from Elsevier.

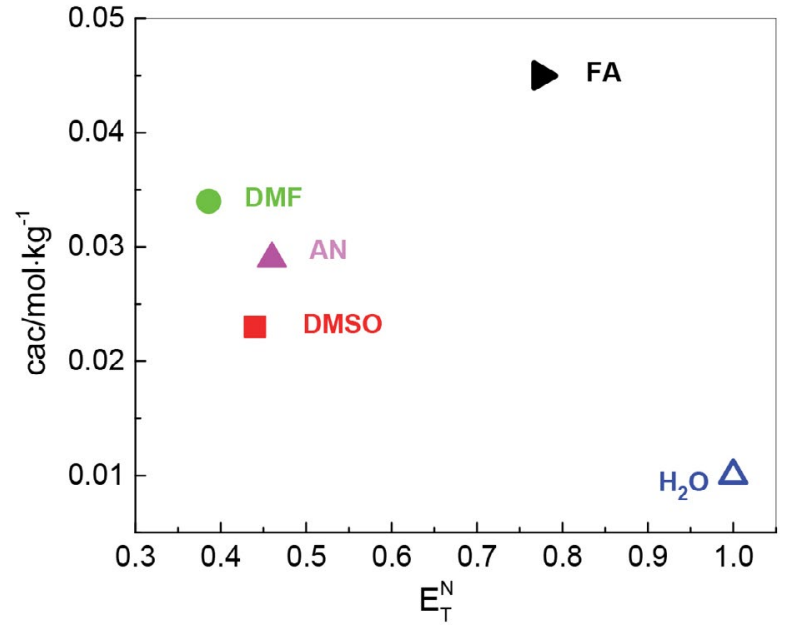

Figure 19. The literature data ${ }^{20}$ of critical aggregation concentration, cac, for $\left[\mathrm{C}_{12} \mathrm{mim}\right] \mathrm{Br}$ in water, DMSO, AN, DMF and FA as a function of empirical parameters for solvent polarity $E_{T}^{N}(30)$.

A larger $E_{T}^{N}(30)$ value reflects weaker interaction between hydrocarbon and the solvents. Thus, interactions of the SAILs alkyl chain with organic solvents increase with decreasing $E_{T}^{N}(30)$ values of the solvents. This reduces the tendency of the SAILs aggregation and increases its cac value, which should increase with decreasing $E_{T}^{N}(30)$ values of the solvents. Obviously, the reported data for DMF, $\mathrm{AN}$ and DMSO are in line with this prediction, but for FA this is not valid. ${ }^{20}$ Thus, despite the fact, that "solvophobic effect" of the solvents plays an important role in the aggregation of the classical surfactants $s^{50,51}$ and SAILs in non-aqueous solvents, also other factors may be important, as it is demonstrated here for the case of FA.

It is necessary to stress that DMSO, DMF and $\mathrm{AN}$ are aprotic solvents, while FA is a protic solvent and capable of forming hydrogen-bonds. Based on molecular dynamics simulations, Hanke et al..$^{52}$ reported that ionic liquids are strongly solvated by the hydrogen-bonding solvents, principally by forming hydrogen bonds with the anions. This indicates that the stronger hydrogen-bonding interactions of the SAILs anions with protic solvents would result in a decrease of the binding degree of the anions at the aggregates surface. In such a case, the electrostatic repulsion between the head groups of the SAIL cannot be decreased effectively, thus weakening the tendency towards aggregation. Therefore, it seems quite likely that the solvophobic effect and the hydrogen-bonding interactions of the SAIL anions with the solvents are the main factors controlling the aggregates formation of SAILs in non-aqueous solvents. Anyway, the work of Feng and coworkers ${ }^{20}$ provides some very important new insight into the roles of solvophobic effect and hydrogen-bonding of non-aqueous solvents in the SAILs aggregation and supplies helpful guide how the aggregation of SAILs could be controlled and regulated by solvent properties.

\section{Concluding Remarks}

It can be concluded that ILs are complex in their pure state, where the structure is strongly dependent on the structures of cations and anions enabling and/or hindering the packaging and/or arrangement of IL molecules. In solutions, ILs behave like simple ("classical") electrolytes and/or common ("classical") surfactants, thus they are sharing the "complexity" of electrolyte solutions. But also in solutions, the structures of the ions play a very important role due to the possibility of diverse ion-ion and ion-solvent interactions. Let me mention only two fields, where the great potential of ILs due to their "tunability" of structures and properties can be used:

a) There is still a lack of theories for concentrated electrolyte solutions. Whereas for "classical" electrolytes the limited solubility could be the reason for less effort in 
studying concentrated solutions, by applying ILs the whole concentration range from pure solvent to pure electrolyte can be covered. Despite many studies, the observed maximum in the electrical conductivity (Figures 8 and 13) is still not described well and remains the challenge for the theoreticians.

b) With their wide possibilities of structures in hydrophobic part and counterions, SAILs are promising systems to study the aggregation processes in non-aqueous solutions.

Therefore, ILs can serve as excellent model systems for studying ionic interactions, hydrophobic effect, and specific ion effect to help us at broadening and deepening the knowledge on electrolyte and surfactant aqueous and non-aqueous solutions.

\section{Acknowledgements}

I would like to thank my colleagues and friends Prof. Dr. Richard Buchner (University of Regensburg, Germany), Prof. Dr. Slobodan Gadžurić (University of Novi Sad, Serbia), Prof. Dr. Milan Vraneš (University of Novi Sad, Serbia), and their Ph. D. students Dr. Johannes Hunger, Dr. Alexander Stoppa, Dr. Sergej Friesen (University of Regensburg, Germany), Dr. Nebojša Zec, Dr. Snežana Papović, and Dr. Aleksandar Tot (University of Novi Sad, Serbia) for the fruitful longstanding collaboration in the field of ionic liquids. Valuable research work of Dr. Bojan Šarac (University of Ljubljana, Slovenia) and Ph. D. students Dr. Martin-Tine Perger, Dr. Ana Kroflič, Dr. Jure Gujt, Dr. Žiga Medoš and Isidora Čobanov is acknowledged.

I am owing my debt to Prof. Dr. Alexander Apelblat (Ben Gurion University of the Negev, Beer-Sheva, Israel) and Dr. Roland Neueder (University of Regensburg, Germany) for sharing his knowledge on electrolyte solutions with me; Prof. Dr. Werner Kunz (University of Regensburg, Germany) for his always optimistic and kind attitude; Dipl. Ing. Herbert Hilbinger (University of Regensburg, Germany) and Dipl. Ing. Dušan Habe (Test and Measurement Technique, Črnomelj, Slovenia) for their permanent and generous technical support.

However, my deepest debt and a profound appreciation go to Professor Josef Barthel, who passed away in February 2019. Not only his friendship, kindness, help, good advice, and pleasant atmosphere in personal relations, but also his long-term support and strong inspiration of my research work encouraged me again and again to follow the - often not easy - scientific way. He supported my application for grant at Alexander von Humboldt foundation and hosted me at the Institute of Physical and Theoretical Chemistry at University of Regensburg (Germany) in 1994/95. After my return, he helped me to build the laboratories at home institution - he supported our application for small-X-ray scattering equipment donation at the $\mathrm{Al}-$ exander von Humboldt foundation and took care of the donation of invaluable pieces of cells to the laboratory for electrical conductivity measurements. Without his generous help I would hardly continue my work. He involved me also in the community of solution chemists and put me on the way, where I met people who have been helping me to gather new knowledge and experiences and to overcome many borders. I am deeply grateful for that and for everything I received from him and I am thankful for all the time that was spent together.

\section{Funding}

The financial support by the Slovenian Research Agency through Bilateral projects (ARRS-BIRS/16-17-023 and ARRS -BI-DE/17-19-4) and through Grant No. P1-0201 is gratefully acknowledged. The networking support by the COST Actions CM1206 and CM1101 is appreciated.

\section{Author biography}

Marija Bešter-Rogač is a Professor of Physical Chemistry at University of Ljubljana, Faculty for Chemistry and Chemical Technology (UL FCCT), where she earned her Ph.D. in 1988. Since her postdoctoral stay in 1994/95 as a fellow of Alexander von Humboldt Foundation at University of Regensburg, at Institute of Physical and Theoretical Chemistry (Germany) with Professor Josef Barthel, she has been active in the broad field of electrolyte solutions and has been involved in strong international collaborations. As author/co-author she published around 120 papers in peer-review journals, some book chapters, two encyclopaedias in the field of electrolyte solutions and carried out several invited lectures at scientific conferences and universities abroad. She has been taken part in many international (COST) and bilateral projects. Most of her recent work is devoted to ionic liquids as possible functional materials and model systems for investigation interactions in solutions.

As a mentor, she has conducted graduate, master's and doctoral theses. In addition, she has participated in various committees and governing bodies at the Faculty and at the University. In 2013/17 she chaired the Commission for Women in Science at Ministry of Education, Science and Sport Republic of Slovenia, and tried for the implementation of fairer relations in the sphere of science and higher education. Since 2018 she is a member of the European Academy of Science and Arts.

\section{References}

1. T. L. Greaves, C. J. Drummond, Chem. Rev. 2015, 115, 1137911448. DOI:10.1021/acs.chemrev.5b00158

2. R-Hayes, G. G. Warr, R. Atkin, Chem. Rev. 2015, 115, 63576426. DOI:10.1021/cr500411q 
3. Y. Ji, R. Shi, Y. Wang, G. Saielli, J. Phys. Chem. B 2013, 117, 1104-1109. DOI:10.1021/jp310231f

4. M. Bešter-Rogač, A. Stoppa, R. Buchner, J. Phys. Chem. B, 2014, 118, 1426-1435. DOI:10.1021/jp412344a

5. M. Bešter-Rogač, J. Hunger, A. Stoppa, R. Buchner, J. Chem. Eng. Data 2010, 55, 1799-1803. DOI:10.1021/je900531b

6. M. Bešter-Rogač, M. V. Fedotova, S. E. Kruchinin, M. Klähn, Phys. Chem. Chem. Phys. 2016, 18, 28594-28605.

DOI:10.1021/je900531b

7. R. Tomaš, A. Tot, J. Kuhar, M. Bešter-Rogač, J. Mol. Liq. 2018, 254, 267-271. DOI:10.1016/j.molliq.2018.01.076

8. B. Šarac, Ž. Medoš, A. Cognigni, K. Bica, L.-J. Chen, M. Bešter-Rogač, Colloid Surf. A 2017, 532, 609-617.

DOI:10.1016/j.colsurfa.2017.01.062

9. H. Olivier-Bourbigou, L. Magna, D. Morvan, Applied Catalysis A: General 2010, 373, 1-56.

DOI:10.1016/j.apcata.2009.10.008

10. V. V. Chaban, O. V. Prezhdo, J. Phys. Chem. Lett. 2013, 4, 1423-1431. DOI:10.1021/jz400113y

11. M. Vraneš, S. Papović, A. Tot, N. Zec, S. Gadžurić, J. Chem. Thermodyn. 2014, 76, 161-171. DOI:10.1016/j.jct.2014.03.025

12. S. Papović, M. Bešter-Rogač, M. Vraneš, S. Gadžurić, J. Chem. Thermodyn. 2016, 99, 1-10. DOI:10.1016/j.jct.2016.03.034

13. S. Papović, M. Vraneš, B. Kordić, S. Filipović, M. BešterRogač, S. Gadžurić, J. Chem. Thermodyn. 2016, 101, 260-269. DOI:10.1016/j.jct.2016.06.012

14. S. Papović, N. Cvjetićanin, S. Gadžurić, M. Bešter-Rogač, M. Vraneš, Phys.Chem.Chem.Phys. 2017, 19, 28139-, 28152. DOI:10.1039/C7CP04478J

15. K. Yuyama, G. Masuda, H. Yoshida, T. Sato, J. Power Sources, 2006, 162, 1401-1408.

DOI:10.1016/j.jpowsour.2006.09.002

16. O. N. Kalugin, I. V. Voroshylova, A. V. Riabchunova, E. V. Lukinova, V. V. Chaban, Electrochim. Acta 2013, 105, 188199. DOI:10.1016/j.electacta.2013.04.140

17. I. V. Voroshylova, S. R. Smaga, E. V. Lukinova, V. V. Chaban, O. N. Kalugin, J. Mol. Liq. 2015, 203, 7-15.

DOI:10.1016/j.molliq.2014.12.028

18. I. Čobanov, B. Šarac, Ž. Medoš, M. Vraneš, S. Gadžurić, N. Zec, M. Bešter-Rogač, J. Mol. Liq. 2018, 271, 437-442. DOI:10.1016/j.molliq.2018.08.152

19. I. Čobanov, B. Šarac, Ž. Medoš, A. Tot, M. Vraneš, S. Gadžurić, N. Zec, M. Bešter-Rogač, J. Mol. Liq. 2020, 301, 112419. DOI:10.1016/j.molliq.2019.112419

20. Q. Feng, H. Wang, S. Zhang, J. Wang, Colloid Surf. A 2010, 367, 7-11. DOI:10.1016/j.colsurfa.2010.05.032

21. Y. Pei, Q. Lu, Y. Niu, Y. Zhao, Y. Zhao, Z. Li, H. Wang, J. Wang, J. Chem. Eng. Data 2019, 64, 4708-4716.

DOI:10.1021/acs.jced.9b00040

22. M. Bešter-Rogač, R. Neueder, J. Barthel, J. Solution Chem. 1999, 28, 1071-1086. DOI:10.1023/A:1022625310402

23. J. M. G. Barthel, H. Krienke, W. Kunz, Physical Chemistry of Electrolyte Solutions: Modern Aspects, Springer, New York, 1998.

24. B. L. Bhargava, M. L. Klein, Soft Matter, 2009, 5, 3475-3480. DOI:10.1039/b908046e
25. O. Nordness, P. Kelkar, M. A. Stadtherr, J. F. Brennecke, Mol. Phys. 2019, 117, 23-24.

DOI:10.1080/00268976.2019.1635276

26. J. F. Casteel, E.S. Amis, J. Chem. Eng. Data 1972, 17, 55-59. DOI:10.1021/je60052a029

27. M. Bešter-Rogač, R. Neueder, J. Barthel, J. Solution Chem. 2000, 29, 51-61. DOI:10.1023/A:1005114500861

28. J. Gujt, M. Bešter-Rogač, B. Hribar-Lee, J. Mol. Liq. 2014, 190, 34-41. DOI:10.1016/j.molliq.2013.09.025

29. G. Hefter, Pure Appl. Chem. 2006, 78, 1571-1586. DOI:10.1351/pac200678081571

30. R. Buchner, Pure Appl. Chem. 2008, 80, 1239-1252. DOI:10.1351/pac200880061239

31. R. Buchner, G. Hefter, Phys. Chem. Chem. Phys. 2009, 11, 8984-8999. DOI:10.1039/b906555p

32. M. Bešter-Rogač A. Stoppa, J. Hunger, G. Hefter, R. Buchner, Phys. Chem. Chem. Phys. 2011, 13, 17588-17598.

DOI:10.1039/c1cp21371g

33. M. Bešter-Rogač, R. Neueder, J. Barthel, Electrolyte Data Collection, Part 5c, in: R. Eckermann, G. Kreysa (Eds.): DECHEMA Chemistry Data Series, Vol XII, Frankfurt, Germany, 2015, p. 222.

34. A. Borun, A. Bald, J. Chem. Eng. Data 2012, 57, 475-481. DOI:10.1021/je201014c

35. A. Borun, A. Bald, Ionics 2016, 22, 859-867. DOI:10.1007/s11581-015-1613-x

36. J. Barthel, L. Iberl, J. Rossmaier, H. J. Gores, B. Kaukal, J. Solution Chem. 1990, 19, 321-337. DOI:10.1007/BF00648139

37. A. Stoppa, J. Hunger, R. Buchner, J. Chem. Eng. Data 2009, 54, 472-479. DOI:10.1021/je800468h

38. M. Bešter-Rogač, R. Neueder, J. Barthel, Electrolyte Data Collection, Part 5c, in: R. Eckermann, G. Kreysa (Eds.): DECHEMA Chemistry Data Series, Vol XII, Frankfurt, Germany, 2015, pp. 416-417.

39. Z. Kiraly, I. Dekany, J. Colloid Interface Sci. 2001, 242, 214 219. DOI:10.1006/jcis.2001.7777

40. R. S. Spolar, J. R. Livingstone, M. T. Record Jr., Biochemistry 1992, 31, 3947-3955. DOI:10.1021/bi00131a009

41. L. J. Chen, Y.-H. Sheu, P.-J. Li, J. Phys. Chem. 2004, 108, 19096-19098. DOI:10.1021/jp045486a

42. G. C. Kresheck, J. Phys. Chem. B 2009, 113, 6732-6735. DOI:10.1021/jp9820469

43. a) F. M. Richards, J. Mol. Biol. 1974, 82, 1-14. DOI:10.1016/0022-2836(74)90570-1

b) F. M. Richards, Annu. Rev. Biophys. Bioeng. 1977, 6, 151176. DOI:10.1146/annurev.bb.06.060177.001055

c) F. M. Richards, Methods Enzymol. 1985, 115, 440-446. DOI:10.1016/0076-6879(85)15032-9

44. G. Singh, T. S. Kang, J. Phys. Chem. B 2016, 120, 1092-1105. DOI:10.1021/acs.jpcb.5b09688

45. S. Friesen, T. Buchner, A. Cognini, K. Bica, R. Buchner, Langmuir, 2017, 33, 9844-9856. DOI:10.1021/acs.langmuir.7b02201

46. B. Šarac, G. Meriguet, B. Ancian, M. Bešter-Rogač, Langmuir 2013, 29, 4460-4469. DOI:10.1021/la400161n

47. A. Kroflič, B. Šarac, M. Bešter-Rogač, J. Chem. Thermodyn. 2011, 43, 1557-1563. DOI:10.1016/j.jct.2011.05.015 
48. A. Ray, J. Am. Chem. Soc. 1969, 91, 6511-6512. DOI:10.1021/ja01051a069

49. C. Reichardt, Solvents and Solvent Effects in Organic Chemistry, Third Edition WILEY-VCH Verlag GmbH \& Co. KGaA, Weinheim, 2003 pp. 418-424.

50. M. L. Moya, A. Rodriguez, M. D. Graciani, G. Femandez, J. Colloid Interface Sci. 2007, 316, 787-795.

DOI:10.1016/j.jcis.2007.07.035
51. M. J. Hollamby, R. Tabor, K. J. Mutch, K. Trickett, J. Eastoe, R.K. Heenan, I. Grillo, Langmuir 2008, 24, 12235-12240. DOI:10.1021/la8020854

52. C. G. Hanke, N. A. Atamas, R. M. Lynden-Bell, Green Chem. 2002, 4, 107-111. DOI:10.1039/b109179b

\section{Povzetek}

Ionske tekočine sodijo med najbolj pogosto preučevane sisteme v zadnjih letih in zanimanje zanje - s poudarkom na razvoju ionskih tekočin za posebne namene kot tudi za temeljne raziskave - še vedno narašča. V tem prispevku so opisane podobnosti in razlike med običajnimi, »klasičnimi« elektroliti ter površinsko aktivnimi snovmi (surfaktanti) in ionskimi tekočinami ter površinsko aktivnimi ionskimi tekočinami. Pregled literaturnih podatkov razkrije, da se ionske tekočine v raztopinah obnašajo kot »klasični« elektroliti in jih lahko opišemo z obstoječimi modeli v območju njihove veljavnosti. Še vedno pa nimamo modelov za opis koncentriranih raztopin elektrolitov in tu lahko ionske tekočine, ki so manj omejene s topnostjo kot običajni elektroliti, služijo kot odlični modelni sistemi. Tudi micelizacijo površinsko aktivnih ionskih tekočin v vodnih raztopinah je mogoče opisati na enak način kot za običajne surfaktante, vendar površinsko aktivne ionske tekočine ponujajo več možnosti za proučevanje vpliva specifičnih ionskih in izomernih efektov na proces micelizacije. Prav tako so ionske tekočine zelo obetavni sistemi za preučevanje agreagacijskih procesov v nevodnih raztopinah.

Except when otherwise noted, articles in this journal are published under the terms and conditions of the Creative Commons Attribution 4.0 International License 